\title{
Prolonged dietary treatment with conjugated linoleic acid stimulates porcine muscle peroxisome proliferator activated receptor $\gamma$ and glutamine- fructose aminotransferase gene expression in vivo
}

\author{
W J Meadus, R Maclnnis, and M E R Dugan \\ Meat Research Section, Agriculture and Agri-Food Canada, Lacombe Research Centre, 6000 C\&E Trail, Lacombe, Alberta, Canada T4L 1W1 \\ (Requests for offprints should be addressed to W J Meadus; Email: meadusj@em.agr.ca)
}

\begin{abstract}
Peroxisome proliferator activated receptors (PPARs) represent a family of DNA binding proteins that are activated by a variety of dietary and endogenous fatty acids. The PPAR proteins are expressed throughout the body and are the target of a variety of lipidaemic and insulin sensitizing drugs. Conjugated linoleic acid (CLA) is a collective name for octadecadienoic acid isomers with conjugated double bonds, which can also act as ligands for some of the PPAR family. To gain better understanding of the long-term effects of PPAR activation, CLA was fed at $11 \mathrm{~g} / \mathrm{kg}$ of feed for 45 days to castrated male pigs (barrows). These barrows had a significant repartitioning of subcutaneous fat to lean tissue in the carcass: fat was reduced by $9.2 \%$ and lean muscle was increased by $3.5 \%$, but intramuscular fat content was also increased by $14 \%(P<0.05)$. PPAR $\gamma$, glutamine-fructose aminotransferase (GFAT), adipocyte fatty acid binding protein (AFABP), but not PPAR $\alpha$ mRNA levels were significantly increased $(P<0.05)$ in the CLA-fed pigs. The increased expression of PPAR $\gamma$ and AFABP indicates that CLA induced the development of preadipocytes from stromal-vascular (s-v) stem cells to promote intramuscular fat content. The increase in the expression of GFAT mRNA indicates that the glucose supply of the muscle cells had been increased with the CLA diet, possibly sparing intramuscular fatty acid reserves.
\end{abstract}

Journal of Molecular Endocrinology (2002) 28, 79-86

\section{Introduction}

Conjugated linoleic acid (CLA) acts as an agonist of the peroxisome proliferator activated receptor (PPAR) family. PPARs are DNA-binding transcription factors that bind the peroxisome proliferator response element (PPRE) (Issemann \& Green 1990, Forman et al. 1995, Oritz et al. 1999) as a heterodimer with the retinoic acid receptor $\mathrm{RxR}$, which is activated by 9-cis-retinoic acid (vitamin A) (Mandrup \& Lane 1997, Mukherjee et al. 1997). The PPAR family are currently divided into three subgroups: $\alpha, \beta$ and $\gamma$. PPAR $\beta$ is expressed throughout the body and is involved in embryo development (Braissant \& Wahli 1998, Michalik \& Wahli 1999). PPAR $\alpha$ is found in liver, skeletal muscle, spleen, kidney, brown adipose and pancreatic $\beta$-islet cells and is primarily responsible for activating genes involved in lipid catabolism
(Kersten et al. 2000) or reducing fatty acid synthesis (Munday \& Hemingway 1999). PPAR $\alpha$ is activated by fatty acids such as linoleic acid, linolenic acid, fibrate-type lipid catabolic drugs and fasting (Hashimoto et al. 2000). PPAR $\gamma$ is found primarily in brown and white adipose tissue and to a lesser extent in spleen, intestine and skeletal muscle. Its activation increases adipocyte differentiation, fat storage, and insulin sensitivity (Brun \& Spiegelman 1997, Valmaseda et al. 1999). PPAR $\gamma$ is activated by 15 deoxy-prostaglandin $\mathrm{J}_{2}$, the insulinsensitizing thiazolidinedione drugs, arachidonic acid (Lehmann et al. 1995) and linoleic acid (Thoennes et al. 2000). PPAR $\alpha$ has a 1000-fold greater affinity for CLA than has $\operatorname{PPAR} \gamma$, but PPAR $\alpha$ and PPAR $\gamma$ both bind the same DNA element PPRE.

In 1997, Dugan and coworkers reported that CLA acted as an effective fat-to-lean 'repartitioning' 
agent in swine. Adding 2\% CLA to the animals' feed increased lean muscle by $2 \cdot 3 \%$ while reducing subcutaneous fat by $6 \cdot 8 \%$ in genetically lean, Large White pigs (Dugan et al. 1997). Surprisingly, however, intramuscular fat content was increased by CLA treatment. The present research was performed to investigate why the two different fat depot sites, subcutaneous and intramuscular, had opposite responses to the CLA diet. Muscle cores were used to prepare total RNA to determine if some of the CLA-induced differences in gene expression reported in vitro could be detected in the whole animal.

\section{Materials and methods}

\section{Animal treatments}

Muscle samples used in this study were from 20 castrated male pigs (barrows) from Landrace boar by Large White sow (Landrace $\times$ Large White) matings (Dugan et al. 1997, 1999). The animals were slaughtered at the Lacombe Research Centre in accordance with the principles and guidelines set by the Canadian Council on Animal Care (1993). Pigs were fed 2\% CLA-enriched oil, equivalent to $11 \mathrm{~g}$ CLA per $\mathrm{kg}$ of feed $(n=10)$ or $2 \%$ sunflower oil (controls; $n=10$ ). The isomeric composition of the CLA feed has been reported previously (Kramer et al. 1998). The diets were formulated to meet nutrient requirements as outlined by the National Research Council (1988). The feeding trial commenced when the pigs reached an average weight of $60 \mathrm{~kg}$, and lasted for 45 days. The pigs were slaughtered at an average weight of $105 \mathrm{~kg}$, as outlined by Dugan et al. (1997). Animal carcass evaluations for lean muscle and subcutaneous fat contents were calculated from in-depth dissections according to the procedures described by Martin et al. (1981). The percentage of intramuscular fat was estimated from dried, ground longissimus thoracis muscle according to Method 39.1.05 of the Association of Official Analytical Chemists (1995).

\section{RNA isolation}

Total RNA was isolated from $100 \mathrm{mg}$ of longissimus thoracis muscle cores using guanidine isothiocyanate-based TRIzol solution (GibcoBrl, Burlington, ON, Canada) according to the manufacturer's specifications (Chomczynski \&
Sacchi 1987). The RNA samples were quantified spectrophotometrically at $260 \mathrm{~nm}$. All RNA isolates had an $\mathrm{OD}_{260}: \mathrm{OD}_{280}$ between $1 \cdot 8$ and $2 \cdot 0$, indicating that they were pure and clean. The quality of RNA was also checked by $1 \cdot 0 \%$ agarose gel electrophoresis and staining with $1 \mu \mathrm{g} / \mathrm{ml}$ ethidium bromide.

\section{Relative reverse transcriptase-polymerase chain reaction (RT-PCR) analysis}

A two-step semi-quantitative RT-PCR method was used to measure gene expression in the longissimus thoracis muscle samples at the time of slaughter. Oligo- $(\mathrm{dT})_{10 n}$ was used as primer in the first step of cDNA synthesis. Total RNA $(5 \mu \mathrm{g})$ was combined with $0.5 \mu \mathrm{g}$ oligo-dT, $200 \mu \mathrm{M}$ dNTPs and $\mathrm{H}_{2} \mathrm{O}$ and preheated at $65^{\circ} \mathrm{C}$ for $2 \mathrm{~min}$ to denature secondary structures. The mixture was then cooled rapidly to $20^{\circ} \mathrm{C}$ and $10 \mu \mathrm{l} 5 \times \mathrm{RT}$ buffer, $10 \mathrm{mM}$ dithiothreitol (DTT) and $200 \mathrm{U}$ Moloney murine leukaemia virus reverse transcriptase (SigmaAldrich, Oakville, ON, Canada) was added to a total volume of $50 \mu$ l. The RT mix was incubated at $37^{\circ} \mathrm{C}$ for $90 \mathrm{~min}$ and the reaction stopped by heating at $95{ }^{\circ} \mathrm{C}$ for $5 \mathrm{~min}$. The cDNA stock was stored at $-20^{\circ} \mathrm{C}$. The yield of cDNA was measured according to the PCR signal generated from the internal standard housekeeping gene, cyclophilin (Genebank accession number AY008846) or $\beta$-actin amplified from 18 to 24 cycles starting with $0 \cdot 1 \mu \mathrm{l}$ of the cDNA solution. The volume of each cDNA pool was adjusted to give the same exponential-phase PCR signal strength for $\beta$-actin after 20 cycles.

Relative RT-PGR (Spencer \& Christensen 1999) was performed to measure gene expression of PPAR $\alpha, \operatorname{PPAR} \gamma$, adipocyte fatty acid binding protein (AFABP), glutamine-fructose aminotransferase (GFAT), acyl-CoA oxidase (ACO) and calpain mRNAs. Primer sequences and optimal PGR annealing temperatures (ta) are listed in Table 1. To ensure that no false-positive PGR fragments would be generated from pseudogenes in contaminating genomic DNA, primer sequences were designed to span intron regions, when genomic sequence data were available. In addition, all PGR primer combinations were tested using porcine genomic DNA as a negative control. PCRs were performed on a PTC-200 PCR machine (MJ Research Inc., Watertown, MA, USA) using 
Table 1 Primers, PCR reaction conditions and expected products used in the semi-quantitative RT-PCR analysis of mRNA levels of the genes expressed in porcine longissimus thoracis muscle

\begin{tabular}{|c|c|c|c|c|}
\hline & Primer sequences & $\begin{array}{l}\text { PCR } \\
\text { product } \\
\text { (bp) }\end{array}$ & $\begin{array}{l}\text { GenBank } \\
\text { accession no. }\end{array}$ & $\begin{array}{l}\text { ta } \\
\left({ }^{\circ} \mathrm{C}\right)\end{array}$ \\
\hline $\begin{array}{l}\text { Gene } \\
P P A R a\end{array}$ & $\begin{array}{l}\text { Sense: } 5^{\prime} \text {-tta cag act acc agt act tag g- } 3^{\prime} \\
\text { Antisense: } 5^{\prime} \text {-agg ctt tgt ccc cac ag- } 3^{\prime}\end{array}$ & 176 & AF175309 & 58 \\
\hline$P P A R \gamma$ & $\begin{array}{l}\text { Sense: } 5^{\prime} \text {-tga cca tgg ttg aca ccg- } 3^{\prime} \\
\text { Antisense: } 5^{\prime} \text {-aag cat gaa ctc cat agt gg- } 3^{\prime}\end{array}$ & 381 & SSC6756 & 58 \\
\hline $\begin{array}{l}A F A B P(\mathrm{aP} 2) \\
\text { Exon } 1 \rightarrow 2\end{array}$ & $\begin{array}{l}\text { Sense: } 5^{\prime} \text {-tgg aaa ctt gtc tcc agt g- } 3^{\prime} \\
\text { Antisense: } 5^{\prime} \text {-ggt act ttc tga cta atg gtg- } 3^{\prime}\end{array}$ & 147 & SSY16039 & 56 \\
\hline Cyclophilin & $\begin{array}{l}\text { Sense: } 5^{\prime} \text {-acc gtc ttc ttc gac atc g- } 3^{\prime} \\
\text { Antisense: } 5^{\prime} \text {-caa cca ctc agt ctt ggc- } 3^{\prime}\end{array}$ & 330 & AY008846 & 62 \\
\hline $\begin{array}{l}\text { Calpain } 1 \\
\text { Exon } 1 \rightarrow 2\end{array}$ & $\begin{array}{l}\text { Sense: } 5^{\prime} \text {-tgg aag gac tgg agc tt gt- } 3^{\prime} \\
\text { Antisense: } 5^{\prime} \text {-gac tcc agg gca tca gct g- } 3^{\prime}\end{array}$ & 152 & SSU23954 & 60 \\
\hline$A C O$ & $\begin{array}{l}\text { Sense: } 5^{\prime}-\mathrm{ccg} \text { gag ctg ctt aca cac at- } 3^{\prime} \\
\text { Antisense: } 5^{\prime} \text {-ggt cat acg tgg ctg tgg tt- } 3^{\prime}\end{array}$ & 427 & AF185048 & 60 \\
\hline GFAT & $\begin{array}{l}\text { Sense: } 5^{\prime} \text {-aac cca gtc ctg tca ata gcc- } 3^{\prime} \\
\text { Antisense: } 5^{\prime} \text {-acg aga gag att gca gct tcc- } 3^{\prime}\end{array}$ & 420 & & 60 \\
\hline$\beta$-Actin & $\begin{array}{l}\text { Sense: } 5^{\prime} \text {-gga ctt cga gca gga gat gg- } 3^{\prime} \\
\text { Antisense: } 5^{\prime} \text {-gca ccg tgt tgg cgt aga gg- } 3^{\prime}\end{array}$ & 233 & SSU07786 & 61 \\
\hline
\end{tabular}

ta, optimal PCR annealing temperature.

$\sim 100 \mathrm{ng}$ cDNA, 5 pmol each oligonucleotide primer, $200 \mu \mathrm{M}$ each dNTP, 1 U REDTaq Polymerase (Sigma-Aldrich, Oakville, ON, Canada) and $1 \times$ REDTaq polymerase buffer in $20 \mu \mathrm{l}$ volume. The PGR program began with a $95^{\circ} \mathrm{C}$ denaturation for $5 \mathrm{~min}$, followed by 30-38 cycles of $95{ }^{\circ} \mathrm{C} / 1 \mathrm{~min}, \mathrm{ta} / 1 \mathrm{~min}, 72^{\circ} \mathrm{C} / 1 \mathrm{~min}$. The linear amplification range for each gene was tested on the adjusted cDNA. $\beta$-Actin primers were added when 20 cycles were remaining in the PGR cycle according to the linear amplification range of the specified gene. The PCR samples were electrophoresed on $8 \%$ polyacrylamide gels $(8 \times 10 \mathrm{~cm})$ or $2 \cdot 5 \%$ agarose Tris-borate-ethylene diamine tetraacetic acid (EDTA) gels. The gels were stained with ethidium bromide $(10 \mu \mathrm{g} / \mathrm{ml})$ and photographed on top of a $280 \mathrm{~nm}$ UV light box. The gel images were digitally captured with a charge coupled device (CCD) camera and analysed with the NIH Imager Beta version 2 program. The quantity and base pair size of the PCR-generated DNA fragments were estimated relative to DNA ladder standards. Densitometry values were measured at each cycle sampling using One-Dscan software (Scanalytics, Fairfax, VA, USA). RT-PGR values are presented as a ratio of the specified gene signal in the selected linear amplification cycle divided by the $\beta$-actin signal.

\section{Protein isolation and analysis}

Protein extracts were prepared from the thawed muscle samples by homogenizing $100 \mathrm{mg}$ of muscle in $1 \mathrm{ml}$ of extract buffer A $(100 \mathrm{mM}$ Tris $\mathrm{HCl} \mathrm{pH}$ $7 \cdot 5,0.5 \mathrm{mM}$ DTT, $2 \mathrm{mM}$ phenymethylsulphonyl fluoride, $5 \mathrm{mM}$ EDTA, $500 \mathrm{mM} \mathrm{NaCl}$, and $0 \cdot 1 \%$ Triton X-100). The homogenate was then centrifuged at $1000 \boldsymbol{g}$ for $5 \mathrm{~min}$ to pellet large cellular debris. Protein concentrations were measured using the bicinchoninic acid assay method (Pierce, Rockford, IL, USA). Samples were diluted to $1 \mu \mathrm{g} / \mu \mathrm{l}$ with extract buffer and then $20 \mu \mathrm{g}$ were mixed with an equal volume of SDS-PAGE loading buffer $(50 \mathrm{mM}$ Tris $\mathrm{HCl} \mathrm{pH} 6 \cdot 8,10 \%$ glycerol, $2 \%$ SDS, 5\% $\beta$-mercaptoethanol, $0.002 \%$ bromophenol blue), heated at $90{ }^{\circ} \mathrm{C}$ for $5 \mathrm{~min}$ and then loaded onto 10\% SDS-PAGE for electrophoresis. To perform the western analysis, the separated proteins were electroblotted to Protran nitrocellulose (Schleicher \& Schuell, Keene, NH, USA) 
and then probed with rabbit anti-m-calpain (Sigma, St Louis, MO, USA), rabbit anti-PPAR (Sigma), and mouse anti-GAPDH (Chemicon Intl Inc., Temecula, CA, USA). The primary antibodies were detected with secondary anti-rabbit or anti-mouse IgG conjugated with alkaline phosphatase to generate a Nitroblue tetrazolium/5bromo-4-chloro-3-indoyl phosphate (NBT/BCIP) signal (Roche Diagnostics, Laval, PQ, Canada). Developed blots were digitally captured with a CGD camera and band intensities were measured as outlined under the RT-PCR methods section.

\section{Statistical analysis}

Data were analysed using GLM Frequency and Correlation procedures (Statistical Analysis System Institute 1985). RT-PGR signals were averaged from at least three replicates using two quantities of cDNA from 10 CLA and 10 control samples. Western blot data were generated from three replicate runs using seven CLA samples and seven control samples. Significance was calculated using Student's $t$-test.

\section{Results}

Market-weight barrows from the study by Dugan et al. (1997) fed with CLA at 2\% of total feed for 45 days had their subcutaneous fat reduced by $9 \cdot 2 \%$, their lean yield increased by $3.5 \%$ and their percentage of intramuscular fat increased by $14 \%$ (Fig. 1). The diets were isocaloric and differed in their composition of 18:2 isomers. Fatty acids in the sunflower diet contained 59\% linoleic acid (18:2n-6), whereas the fatty acids in the CLA diet had 25.4\% linoleic acid and 32.85\% CLA (mixed isomers) (Dugan et al. 1999). Thus both the control and the CLA diets were nearly equivalent with respect to their content of polyunsaturated fatty acids (PUFA; controls $62.5 \%$, compared with CLA $61 \cdot 21 \%)$. The effects on animal physiology of dietary PUFA compared with mono- and saturated fatty acids have been well studied (see review by Clarke 2000). The present research compared the effect of different types of PUFAs, specifically CLAs, which are believed to have a high affinity for the PPAR family of nuclear transcription factors (Moya-Carmarena et al. 1999, Thoennes et al. 2000).

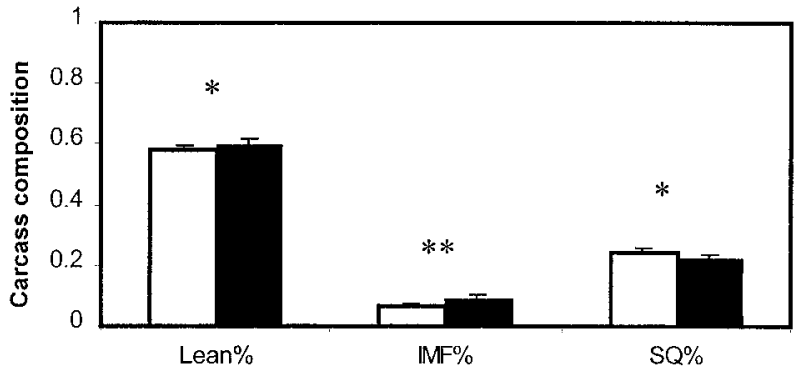

Figure 1 The effect of feeding $2 \%$ conjugated linoleic acid (CLA) for 45 days on the carcass composition of market-weight pigs. Carcass compositions were measured as outlined in Materials and methods. Lean (Lean\%) and subcutaneous (SQ\%) fat are expressed as percentages per $\mathrm{kg}$ of body weight, and percentage intramuscular fat (IMF\%) is expressed as grams of lipid per gram of muscle on a dry matter basis. Error bars represent standard deviation. $\square$, Controls; $\square, 2 \%$ CLA-fed. Significant differences: ${ }^{\star} P<0.05$, ${ }^{* \star} P<0 \cdot 01$.

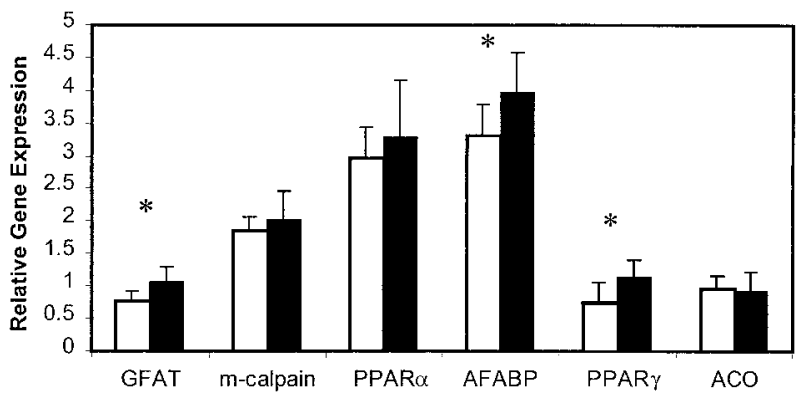

Figure 2 Adult muscle gene expression in barrows fed $2 \%$ CLA ( $\square, n=10)$ compared with animals fed the control sunflower diet ( $\square, n=10)$. Quantities of gene transcripts were measured by relative RT-PCR using the internal standard $\beta$-actin RT-PCR signal as the denominator, as described in Materials and methods. Error bars represent standard deviation. Significant differences: ${ }^{\star} P<0.05,{ }^{* *} P<0.01$.

The relative levels of gene expression in longissimus thoracis muscle from pigs fed either the control diet with $2 \%$ sunflower oil or the test diet with 2\% CLA-enriched oil are shown in Fig. 2. In the longissimus thoracis muscle of animals fed $2 \%$ CLA, GFAT, AFABP, and PPAR $\gamma$ mRNAs were significantly $(P<0.05)$ increased, by $36.1 \%, 20 \cdot 4 \%$ and $26 \cdot 0 \%$ respectively (Fig. 3). However, western blotting analysis (data not shown) revealed no difference in PPAR protein contents of longissimus thoracis muscle after control or CLA treatments.

Because intramuscular adipose was not dissected from the lean muscle tissue for individual testing of RNA, it was possible that the observed increase in 


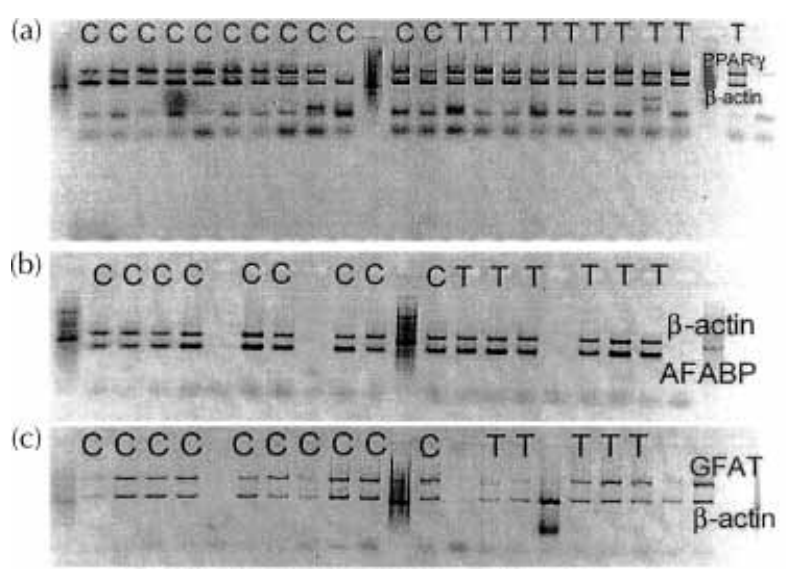

Figure 3 Gel image of relative RT-PCR. (a) PPAR $\gamma$ at 34 cycles with $\beta$-actin added at cycle 14 to act as the internal control. (b) GFAT at 34 cycles with $\beta$-actin added at cycle 14. (c) AFABP at cycle 26 with $\beta$-actin added at cycle 4. C, control animals. T, CLA-fed animals.

PPAR $\gamma$ expression was an artefact of the increased percentage of intramuscular fat in the longissimus thoracis muscle of the CLA-fed group. To investigate the possibility of sampling variance, a muscle:fat ratio was calculated using the gene markers for m-calpain (muscle) and AFABP (adipocytes). There was still a significant increase in GFAT and PPAR $\gamma$ mRNA expression in the $2 \%$ CLA-fed animals after adjustment was made for the relative content of fat in each muscle sample (Fig. 3).

Calpain was chosen as a muscle-specific gene marker, but was also a potential indicator of muscle protein deposition rates, as it functions as an endogenous protease (Huang \& Forsberg 1998). Some studies in swine have found that dietary CLA increased fasting concentrations of serum insulin (Stangl et al. 1999), which may have increased lean body mass by reducing muscle catabolism (Rooyackers \& Nair 1997), as indicated by increased nitrogen retention in the CLA-fed pigs (Muller et al. 2000). One of the known effects of insulin is to reduce muscle protein catabolism, possibly by reducing gene expression of proteases such as calpain (Fernandez \& Sainz 1997). The CLA diet did not cause a significant change in calpain mRNA or protein levels as determined by western blot analysis. This was not surprising, because m-calpain does not have a PPRE element in its promoter region, but it does not rule out the possibility that the gene activity of $\mathrm{m}$-calpain or some other protease was decreased by the CLA treatment.

AFABP is adipocyte-specific and is known to contain active PPRE sites in its upstream promoter region (Houseknecht et al. 1998, Gerbens et al. 2000) and, as expected, 2\% CLA did increase the expression of the AFABP gene in this trial, by $26 \%$ $(P<0 \cdot 05$; Fig. 3). Expression of ACO mRNA was also examined, as it is a known muscle and liver peroxisomal enzyme that is induced during lipid excess and by CLA in liver cells (Moya-Camarena \& Belury 1999). ACO mRNA expression in the longissimus thoracis tissue was not significantly affected by the CLA diet.

Expression of the GFAT gene was significantly increased in muscle core samples from the CLA-fed animals. GFAT is the rate-limiting enzyme in the hexosamine pathway, which is involved in producing glycosylation substrates during periods of excess available intercellular glucose (Wang et al. 1998). Expression of GFAT is increased when plasma concentrations of glucose or fatty acids are high (Hawkins et al. 1997).

\section{Discussion}

In this study, barrows fed 2\% CLA-enriched oil for 45 days had a significant reduction in subcutaneous fat compared with pigs fed diets containing 2\% sunflower oil. However, 2\% CLA also significantly increased the percentage of intramuscular fat. These changes in physiology are believed to be due to CLA activating the nuclear transcription factor, PPAR (Isseman \& Green 1990). In this trial, longissimus thoracis expression of PPAR $\gamma$ mRNA and the PPAR-responsive gene, $A F A B P$, were significantly increased by dietary treatment with CLA. CLA treatment reduces subcutaneous fat in rats by increasing carnitine palmitoyltransferase and fatty acid $\beta$-oxidation activity in mature adipocytes, but not in skeletal muscle (Martin et al. 2000). The conflicting increase in intramuscular fat deposits and associated reduction in subcutaneous fat deposits in CLA-fed animals may be due to differences in PPAR expression and adipocyte cellular development between the two fat locations (Brun \& Spiegelman 1997, Grindflek et al. 1998, Valmaseda et al. 1999). Intramuscular fat and muscle tissue have a higher percentage of $\mathrm{s}-\mathrm{v}$ stem 
cells and preadipocytes than subcutaneous fat (Ramsay et al. 1989, May et al. 1994). It has also been demonstrated in vitro that $\mathrm{s}-\mathrm{v}$ cells, fibroblasts and newborn mouse muscle stem cells can be induced to differentiate into preadipocytes and to express adipocyte-specific genes such as $A F A B P$, by treating them with PPAR $\gamma$ activators such as thiazolidinedione drugs (Lehmann et al. 1995, Teboul et al. 1995). Therefore, it was possible that prolonged PPAR stimulation by CLA increased the apparent intramuscular fat content because more stem cells were available for intramuscular fat than for subcutaneous fat locations.

Recent studies in pigs have shown that prolonged dietary treatment with 3\% CLA increases the fasting plasma concentrations of both free fatty acids and insulin (Stangl et al. 1999). Insulin production and PPARa gene expression in pancreatic $\beta$-islet cells are inversely related: PPARa gene expression is inhibited in pancreatic $\beta$-cells during glucose and free fatty acid feeding (Roduit et al. 2000) and increased during fasting (Kroetz et al. 1998, Hashimoto et al. 2000). The prolonged high dose of dietary CLA may be suppressing pancreatic PPAR $\alpha$, thus allowing the production of more insulin. One of the effects of increased insulin sensitivity is increased protein retention as a result of reduced skeletal muscle catabolism (Rooyackers \& Nair 1997), and CLA has been shown to increase lean muscle mass significantly. The relationship between increased insulin sensitivity and skeletal muscle protein retention is complex. Plasma insulin increases the number of insulin receptors and glucose transporters on the plasma membrane of skeletal muscle (Ezaki 1997, Park et al. 1998). The net effect is increased glucose destined for oxidation, with a potential sparing of dietary amino acids for protein synthesis, thereby reducing the need for protein catabolism to supply glycogenic amino acids (Baier et al. 2000). The protease, $\mathrm{m}$-calpain, is an indicator for the catabolic enzymes that would theoretically be reduced during high glucose feeding and increased insulin concentrations (Fernandez \& Sainz 1997, Wingertzahn et al. 1998), although m-calpain was not significantly reduced by CLA in the present trial. However, expression of GFAT mRNA was significantly increased. This supports the hypothesis that, in the CLA-fed pigs, muscle was supplied with greater amounts of energy, as GFAT and the hexosamine pathway are increased when increased intercellular concentrations of glucose are available. Muscle glucose might have been spared as a result of the availability of more plasma triacylglycerols, which are typically increased by CLA diets (Stangl et al. 1999).

\section{Conclusions}

The semi-quantitative RT-PGR results show that prolonged dietary administration of CLA increased gene transcription of PPAR $\gamma$, GFAT and the PPARinducible $A F A B P$ gene in longissimus thoracis muscle core samples. Lean muscle, but also intramuscular fat content, were increased in the CLA-fed pigs. This indicates that CLA increased the percentage of intramuscular fat as a result of a combination of local stem cells being recruited into an adipocyte lineage by CLA activation of the nuclear transcription factor, PPAR $\gamma$, and increased nutrient supply in and around muscle. The increase in percentage lean muscle mass in CLA-fed pig carcasses may be due to an increase in the basal concentration of insulin, which would increase muscle glucose uptake, as indicated by the increase in GFAT mRNA.

\section{Acknowledgements}

Agri-Food \& Agriculture Canada supplied financial support for this work.

\section{References}

Association of Official Analytical Chemists 1995 Method 39.1.05. In Official Methods of AOAC International, edn 16. Washington DC: AOAC.

Baier LJ, Permana PA, Yang X, Pratley RE, Hanson RL, Shen G, Mott D, Knowler WC, Cox NJ, Horikawa Y, Oda N, Bell GI \& Bogardus C 2000 A calpain-10 gene polymorphism is associated with reduced muscle mRNA levels and insulin resistance. Fournal of Clinical Investigation 106 R69-R73.

Braissant O \& Wahli W 1998 Differential expression of peroxisome proliferator-activated receptor $-\alpha,-\beta$, and $-\gamma$ during rat embryonic development. Endocrinology $1392748-2754$.

Brun RP \& Spiegelman BM 1997 Obesity and the adipocyte. PPAR $\gamma$ and the molecular control of adipogenesis. Fournal of Endocrinology 155 217-218.

Canadian Council on Animal Care 1993 Guide to the Care and Use of Experimental Animals, vol 1. Eds ED Olfert, BM Cross \& AA McWilliam. Ottawa, Canada: CCAC.

Chomczynski P \& Sacchi N 1987 Single step method of RNA isolation by acid guanidinium thiocyanate-phenol-chloroform extraction. Analytical Biochemistry 161 156-159. 
Clarke SD 2000 Polyunsaturated fatty acid regulation of gene transcription: a mechanism to improve energy balance and insulin resistance. British Fournal of Nutrition 83 S59-S66.

Dugan MER, Aalhus JL, Schaefer AL \& Kramer JKG 1997 The effect of conjugated linoleic acid on fat to lean repartitioning and feed conversion in pigs. Canadian Fournal of Animal Science $\mathbf{7 7}$ $723-725$.

Dugan MER, Aalhus JL, Jeremiah LE, Kraemer JKG \& Schaefer AL 1999 The effect of feeding conjugated linoleic acid on subsequent pork quality. Canadian Fournal of Animal Science $\mathbf{7 9}$ $45-51$.

Ezaki O 1997 Regulatory elements in the insulin-responsive glucose transporter (GLUT4) gene. Biochemical and Biophysical Research Communications 241 1-6.

Fernandez C \& Sainz RD 1997 Pathways of protein degradation in L6 myotubes. Proceedings of the Society of Experimental and Biological Medicine 214 242-247.

Forman BM, Tontonoz P, Chen J, Brun RP, Spiegelman BM \& Evans RM 1995 15-Deoxy- $\delta^{12,14}$-prostaglandin $\mathrm{J}_{2}$ is a ligand for the adipocyte determination factor PPAR $\gamma$. Cell $\mathbf{8 3} 803-812$.

Gerbens F, de Koning DJ, Harders FL, Meuwissen THE, Janss LGG, Groenen MAM, Veerkamp JH, Van Arendonk JAM \& te Pas MFW 2000 The effect of adipocyte and heart fatty acid-binding protein genes on intramuscular fat and backfat content in Meishan crossbred pigs. Fournal of Animal Science 78 $552-559$.

Grindflek E, Sundvold H, Klungland H \& Lien S 1998 Characterisation of porcine peroxisome proliferator-activated receptors $\mathrm{g} 1$ and $\mathrm{g} 2$ : detection of breed and age differences in gene expression. Biochemical and Biophysical Research Communications $249713-718$.

Hashimoto T, Cook WS, Qi C, Yeldandi AV, Reddy JK \& Rao MS 2000 Defect in peroxisome proliferator-activated receptor alpha-inducible fatty acid oxidation determines the severity of hepatic steatosis in response to fasting. Fournal of Biological Chemistry 275 28918-28928.

Hawkins M, Angelov I, Liu R, Barzilai N, \& Rossetti L 1997 The tissue concentration of UDP- $\mathcal{N}$-acetylglucosamine modulates the stimulatory effect of insulin on skeletal muscle glucose uptake. Journal of Biological Chemistry 272 4889-4895.

Houseknecht KL, Vanden Heuvel JP, Moya-Camarena SY, Portocarrero CP, Peck LW, Nickel KP \& Belury MA 1998 Dietary conjugated linoleic acid normalizes impaired glucose tolerance in the Zucker diabetic fatty fa/fa rat. Biochemical and Biophysical Research Communications 244 678-682.

Huang J \& Forsberg NE 1998 Role of calpain in skeletal-muscle protein degredation. PNAS 95 12100-12105.

Issemann I \& Green S 1990 Activation of a member of the steroid hormone receptor superfamily by peroxisome proliferators. Nature 347 645-650.

Kersten S, Desvergne B \& Wahli W 2000 Roles of PPARs in health and disease. Nature $\mathbf{4 0 5} 421-424$.

Kramer JKG, Sehat N, Dugan MER, Mossoba MM, Yurawecz MP, Roach JAG, Eulitz K, Aalhus JL, Schaefer AL \& Ku Y 1998 Distribution of conjugated linoleic acid (CLA) isomers in tissue lipid classes of pigs fed a commercial CLA mixture determined by gas chromatography and silver ion high-performance liquid chromatography. Lipids 33 549-558.

Kroetz DL, Yook P, Costet P, Bianchi P \& Pineau T 1998 Peroxisome proliferator-activated receptor alpha controls the hepatic CYP4A induction adaptive response to starvation and diabetes. Fournal of Biological Chemistry 273 31581-31589.

Lehmann JM, Moore LB, Smith-Oliver TA, Wilkison WO, Willson TM \& Kliewer SA 1995 An antidiabetic thiazolidinedione is a high affinity ligand for peroxisome proliferator activated receptor- $\gamma$. Fournal of Biological Chemistry 270 12953-12956.
Mandrup S \& Lane MD 1997 Regulating adipogenesis. Fournal of Biological Chemistry 272 5367-5370.

Martin AH, Fredeen HT, Weiss GM, Fortin A \& Sim D 1981 Yield of trimmed pork product in relation to weight and backfat thickness of the carcass. Canadian Fournal of Animal Science $\mathbf{6 1}$ 299-310.

Martin JC, Gregoire S, Siess MH, Gentry M, Chardigny JM, Berdeaux O, Juaneda P \& Sebedio JL 2000 Effect of conjugated linoleic acid isomers on lipid-metabolizing enzymes in male rats. Lipids 35 91-98.

May SG, Savell JW, Lunt DK, Wilson JJ, Laurenz JC \& Smith SB 1994 Evidence for preadipocyte proliferation during culture of subcutaneous and intramuscular adipose tissues from Angus and Wagyu crossbred steers. Fournal of Animal Science 72 3110-3117.

Michalik L \& Wahli W 1999 Peroxisome proliferator-activated receptors: three isotypes for a multitude of functions. Current Opinion in Biotechnology 10 564-570.

Moya-Camarena SY \& Belury MA 1999 Species differences in the metabolism and regulation of gene expression by conjugated linoleic acid. Nutrition Reviews 57 336-340.

Moya-Carmarena ST, Vanden Heuval JP, Blanchard SG, Leesnitzer LA \& Belury MA 1999 Conjugated linoleic acid is a potent naturally occurring ligand and activator of PPARa. Fournal of Lipid Research 40 1426-1433.

Mukherjee R, Jow L, Croston GE \& Paterniti JR 1997 Identification, characterization, and tissue distribution of human peroxisome proliferator-activated receptor (PPAR) isoforms PPAR $\gamma 2$ versus PPAR $\gamma 1$ and activation with retinoid $\mathrm{X}$ receptor agonists and antagonists. Fournal of Biological Chemistry 272 8071-8076.

Muller HL, Kirchgessner M, Roth FX \& Stangl GI 2000 Effect of conjugated linoleic acid on energy metabolism in growingfinishing pigs. Fournal of Animal Physiology and Animal Nutrition 83 85-94.

Munday MR \& Hemingway CJ 1999 The regulation of acetyl-CoA carboxylase - a potential target for the action of hypolipidemic agents. Advances in Enzyme Regulation 39 205-234.

National Research Council 1988 Nutrient Requirements of Swine, edn 9. Washington, DC: National Academy Press.

Oritz JA, Mallolas J, Nicot C, Bofarull J, Rodriguez JC, Hegardt FG, Haro D \& Marrero PF 1999 Isolation of pig mitochondrial 3-hydroxy-3-methylglutaryl-CoA synthase gene promoter: characterization of a peroxisome proliferator-responsive element. Biochemical Foumal 337 329-335.

Park KS, Ciaraldi TP, Lindgren K, Abrams-Carter L, Mudaliar S, Nikoulina SE, Tufari SR, Veerkamp JH, Vidal-Puig A \& Henry RR 1998 Troglitazone effects on gene expression in human skeletal muscle of type II diabetes involve up-regulation of peroxisome proliferator-activated receptor-gamma. Fournal of Clinical Endocrinology and Metabolism 83 2830-2835.

Ramsay TG, White ME \& Wolverton CK 1989 Glucocorticoids and the differentiation of porcine preadipocytes. Fournal of Animal Science $672222-2229$.

Roduit R, Morin J, Masse F, Segall L, Roche E, Newgard CB, Assimacopoulos-Jeannet F \& Prentki M 2000 Glucose down-regulates the expression of the peroxisome proliferator-activated receptor-alpha gene in the pancreatic beta-cell. Fournal of Biological Chemistry 275 35799-35806.

Rooyackers OE \& Nair KS 1997 Hormonal regulation of human muscle protein metabolism. Annual Review of Nutrition $\mathbf{1 7}$ $457-485$.

Spencer WE \& Christensen MJ 1999 Multiplex relative RT-PCR method for verification of differential gene expression. BioTechniques 27 1044-1052.

Stangl GI, Muller H \& Kirchgessner M 1999 Conjugated linoleic acid effects on circulating hormones, metabolites and lipoproteins, 
and its proportion in fasting serum and erythrocyte membranes of swine. European Fournal of Nutrition $38271-277$.

Statistical Analysis System Institute 1985 SAS User's Guide: Statistics, edn 5. Cary, NC, USA: SAS Institute Inc.

Teboul L, Gaillard D, Staccini L, Inadera H, Amri E-Z \& Grimaldi PA 1995 Thiazolidinediones and fatty acids convert myogenic cells into adipose-like cells. Fournal of Biological Chemistry $\mathbf{2 7 0}$ 28183-28187.

Thoennes SR, Tate PL, Price TM \& Kilgore MW 2000 Differential transcriptional activation of peroxisome proliferator-activated receptor gamma by omega- 3 and omega- 6 fatty acids in MCF-7 cells. Molecular and Cellular Endocrinology 160 67-73.

Valmaseda A, Carmona MC, Barbera MJ, Vinas O, Mampel T, Inglesias R, Villarroya F \& Giralt M 1999 Opposite regulation of
PPAR-a and -g gene expression by both their ligands and retinoic acid in brown adipocytes. Molecular and Cellular Endocrinology 154 101-109.

Wang J, Liu R, Hawkins M, Barzilai N \& Rossetti L 1998 A nutrient sensing pathway regulates leptin gene expression in muscle and fat. Nature $393684-688$.

Wingertzahn MA, Zdanowicz MM \& Slonim AE 1998 Insulin-like growth factor-1 and high protein diet decrease calpain-mediated proteolysis in murine muscular dystrophy. Proceedings of the Society of Experimental Biology and Medicine 218244250.

Received 25 October 2001

Accepted 20 November 2001 